Faculty of Law,

Economics

and Finance

Law Working Paper Series

Paper number 2018-007

\title{
Portability of Student Benefits in the European Union
}

The Luxembourg System

Janine Silga, University of Luxembourg janine.silga@uni.lu 


\title{
PORTABILITY OF STUDENT BENEFITS IN THE EUROPEAN UNION - THE LUXEMBOURG SYSTEM
}

\author{
Janine Silga \\ Postdoctoral researcher at the University of Luxembourg
}

\section{Introduction}

Since its creation, Luxembourg's system of financial aid for higher (university) studies has set as its primary objective the increase of the proportion of its resident population holding a higher education degree. ${ }^{1}$ However, the fact that Luxembourg did not have its own university system until $2003^{2}$ made this country even more dependent on other European countries to fulfil this policy objective. This explains why the portability of national financial assistance for higher education was crucial to achieve it. In the European Union (EU) context, the portability - or exportability - of student grants or loans may be defined as the faculty for students to 'export' such benefits to a Member State that is different from the one which allocates them. ${ }^{3}$ Portability is also the reason why the Luxembourg system falls into the scope of EU law, since it may interfere with equal treatment between workers all the more so, as frontier workers ${ }^{4}$ account for more than $45 \%$ of the country's labour force. ${ }^{5}$ These peculiarities provide the background for the three decisions of the Court of Justice of the EU (CJEU) on the portability of financial aid for higher studies for children of frontier workers that lie at the heart of this paper. It will start by briefly highlighting the evolution of Luxembourg's system of financial aid for higher

\footnotetext{
${ }^{1}$ See the Opinion of the Council of State of 21.03.2000 on draft legislation no. 4562, leading to the adoption of the Loi du 22 juin 2000 concernant l'aide financière de l'Etat pour études supérieures.

${ }^{2}$ Loi du 12 aout 2003 portant création de l'Université du Luxembourg, Mémorial A no. 149 of 6 October 2003, p. 2290.

${ }^{3}$ For more details on the portability of financial aid for higher education in the EU, read: M. Jacobs and L. Van den Broeck, 'A quelles conditions les étudiants peuvent-ils étudier à l'étranger avec une bourse d'étude de l'Etat Membre de résidence’?, Journal de droit européen, vol. 194, 2012, pp. 289-294 ; A.-C. Simon, 'La portabilitité des bourses d'études dans l’Union européenne’, European Journal of Consumer Law, 2007-2008, pp. 66-86 and H. Skovgaard-Petersen, 'There and back again : portability of students loans, grands and fee support in a free movement perspective', European Law Review, vol. 36(6), 2013, pp. 783-804.

${ }^{4}$ Article 1(f) of the Regulation no. 883/2004 on the coordination of social security systems defines a frontier worker as 'any person pursuing an activity as an employed or self-employed person in a Member State and who resides in another Member State to which he returns as a rule daily or at least once a week'. Regulation (EC) no. 883/2004 of the European Parliament and of the Council of 29 April 2004 on the coordination of social security systems, OJEU L 166/1 of 30.04.2004.

${ }^{5}$ http://m.statistiques.public.lu/stat/TableViewer/tableViewHTML.aspx?ReportId=12916\&IF_Language=fra\&M ainTheme $=2 \&$ FldrName=3\&RFPath=92 (18/04/2018)
} 
education and present its main features. Then, it will show that despite the recent clarifications given by the CJEU in the last two cases of 2016, several issues remain unanswered, both from an EU and national law perspective.

\section{The evolution of the Luxembourg System for Financial Aid for Higher Studies: A System based on Portability}

Portability has been provided since the creation of financial aid for higher studies in $1977 .{ }^{6}$ In accordance with both EU primary ${ }^{7}$ and secondary ${ }^{8}$ law, Member States are free to make the maintenance assistance for studies portable or not. In fact, only a minority of Member States provide for such a possibility, one of them being Luxembourg. Initially, financial aid was only available to residents (whether nationals or children of EU migrant workers) but following the Giersch case, ${ }^{9}$ this possibility was extended to children of frontier workers on the basis of the principle of equal treatment. ${ }^{10}$ In 2016, two additional cases of the CJEU (hereinafter Bragança Linares Verruga ${ }^{11}$ and Depesme ${ }^{12}$ ) further specified the personal scope of financial aid.

The current system of financial aid for higher education was established through the adoption of a legislative act of 22 June $2000 .{ }^{13}$ Financial aid for higher studies is primarily composed of a grant and a subsidised loan ${ }^{14}$ and the proportion of each element varies according to the financial and social situation of the students and his parents, as well as registration fees. ${ }^{15}$ Financial aid may also be increased after taking into account enrolment fees or in exceptional circumstances. ${ }^{16}$ Under the original scheme, an incentive bonus ('prime d'encouragement') could also be awarded to students on the basis of their academic merit. ${ }^{17}$ This system was

\footnotetext{
${ }^{6}$ Loi du 8 décembre 1977 concernant l'aide financière de l'Etat pour études supérieures, Mémorial A no. 73 of 10 December 1977, p. 2102.

${ }^{7}$ Article 165(1) TFEU clearly states that Member States are responsible '...[f]or the content of teaching and the organisation of education systems and their cultural and linguistic diversity.'

${ }^{8}$ See recital 21 as well as article 24(2) of Directive 2004/38 on the right of citizens of the Union and their family members to move and reside freely within the territory of the Member States, OJEU L 158/77 of 30.04.2004.

9 Judgment of 20 June 2013, Elodie Giersch and Others v État du Grand-Duché de Luxembourg, C-20/12, EU:C:2013:411

${ }^{10}$ For more details on this case-law, see developments below under point 1.2.

11 Judgment of 14 December 2016, Maria do Céu Bragança Linares Verruga and Others v Ministre de l'Enseignement supérieur et de la recherche, C-238/15, EU:C:2016:949.

12 Judgment of 15 December, Noémie Depesme and Others v Ministre de l'Enseignement supérieur et de la recherche, joined cases C-401/15 to C-403/15, EU:C:2016:955.

${ }^{13}$ Loi du 22 juin 2000 concernant l'aide financière de l'Etat pour études supérieures, Mémorial A no. 49 of 28 June 2000, p. 1106.

${ }^{14}$ Article 1(1) of Loi du 22 juin 2000 concernant l'aide financière de l'Etat pour études supérieures.

${ }^{15}$ Article 4(1) of Loi du 22 juin 2000 concernant l'aide financière de l'Etat pour études supérieures.

${ }^{16}$ Article 4(1) and 8(2) of Loi du 22 juin 2000 concernant l'aide financière de l'Etat pour études supérieures, now article 6 of Loi du 24 juillet 2014 concernant l'aide financière de l'Etat pour études supérieures.

${ }^{17}$ Article 1(1) and 4(4) of Loi du 22 juin 2000 concernant l'aide financière de l'Etat pour études supérieures.
} 
modified several times, especially to make it consistent with EU law. This was the case of the 2005 amendment adopted to abolish a discrimination on grounds of nationality, which had been identified by national courts themselves. ${ }^{18}$ Indeed, the original legislation imposed a residence condition (or 'domicile ${ }^{19}$ ) only for non-national students. ${ }^{20}$

A more substantial reform of the system took place in $2010^{21}$ with a view to change its underlying 'paradigm'. The new system was supposed to enable all students to carry out higher education studies, independently and regardless of their parents' income or wishes. ${ }^{22}$ Therefore, only the student's income was taken into account to calculate the proportion between the amount of the grant and the loan, unlike that proposed by the initial text. ${ }^{23}$ The incentive bonus was also repealed. ${ }^{24}$ This new system was part of a more general reform of family benefits, ${ }^{25}$ namely family allowances (allocations familiales) and child bonus (boni pour enfant). Among other things, this reform - stemming from the 2010 legislation - cancelled family allowances for children above 18 who were carrying out higher education. Family allowances for children beyond that age were only maintained if they were pursuing secondary education. ${ }^{26}$ Interestingly, the child bonus was granted directly to the student as a part of their financial aid for higher studies, the objective being to make the student even more financially independent. However, the renewed system maintained a residence condition which the CJEU ruled incompatible with EU law in Giersch, insofar as it constituted indirect discrimination against

\footnotetext{
${ }^{18}$ Administrative Court, decision of 12 July 2004, application no. 17568, confirmed by the Higher Administrative Court, decision of 25 January 2005, application no. 18539C.

${ }^{19}$ In Giersch, the Luxembourg Administrative Court argued that the notion of domicile and residence 'cover the same factual concept, that is to say the place where the person concerned actually, lawfully and continuously lives', paragraph. 29.

${ }^{20}$ Loi du 4 avril 2005 modifiant la loi du 22 juin 2000 concernant l'aide financière de l'Etat pour études supérieures, Mémorial A, no. 50 of 20 April 2005. Specific arrangements were adopted for Luxembourg nationals residing abroad who were adversely affected by this reform and wished to maintain a domicile in Luxembourg. See J. Gerkrath, 'Des aides financières discriminatoires? - L’arrêt de la Cour de Justice de l’Union européenne dans l'affaire Elodie Giersch et autres contre Etat du Grand-Duché de Luxembourg', Politik, February 2014, pp. 7-10, at p. 8. Read also the Report of the Committee for Higher Education and Research of 16.02.2005, on the draft legislation no. 5407 for the amendment of the Loi du 22 juin 2000 concernant l'aide financière de l'Etat pour études supérieures, at p. 3.

${ }^{21}$ Loi du 26 juillet 2010 amending among others - and for the second time - the loi du 22 juin concernant l'aide financière de l'Etat pour études supérieures, Mémorial A no. 118 of 27 July 2010, p. 2039.

${ }^{22}$ See draft legislation no. 6148 of 18.06 .2010 amending for the second time the Loi du 22 juin 2000 concernant l'aide financière de l'Etat pour études supérieures, p. 2. This approach has been criticised by the Council of State on the grounds that it did not favour social equality since the criteria for attributing financial aid did not include parents' income but only the income of the student. In its view, the depiction of a student that would be entirely independent from the family household was akin to a legal fiction. Opinion of the Council of State on draft legislation no. 6148, at p.2. Read also J. Gerkrath, op. cit., p. 7.

${ }^{23}$ Article $1\left(4^{\circ}\right)$ of Loi du 26 juillet 2010

${ }^{24}$ Article $1\left(1^{\circ}\right)$ of Loi du 26 juillet 2010.

${ }^{25}$ For more details on this point, read draft legislation no. 6148 of 18.06 .2010 amending - for the second time the Loi du 22 juin 2000 concernant l'aide financière de l'Etat pour études supérieures, pp. 2-3.

${ }^{26}$ Currently article 271(2) of the Social Security Code.
} 
children of frontier workers. ${ }^{27}$ Following this case, the 2000 legislative act was amended for the third time in $2013,{ }^{28}$ through the addition of two more articles. Article 2bis, on the one hand, required that children of frontier workers could only benefit from Luxembourg financial aid for higher education if their parent(s) had worked continuously for at least five years prior to the application for funding. This article further specified that the parent frontier worker should work on the basis of at least half the duration of normal working time in Luxembourg. This latter article was again scrutinised by the Court in two cases ruled in 2016. These cases answered two questions: first, whether the condition of a continuous period of work of five years imposed on a frontier worker parent was in conformity with EU law (Bragança Linares Verruga) and second, whether step-children could be considered 'children' of a frontier worker for the purpose of being eligible to the national system of financial aid (Depesme). In both instances, the CJEU further widened the personal scope of Luxembourg system of maintenance aid for higher studies.

On the other hand, because the new amending legislation had made financial aid accessible to children of frontier workers, a new article 5bis was also introduced to prevent the overlap with other similar funding systems that could be granted by the country of residence. Beside the prevention of possible abuse, this new article intended to prevent 'reverse discrimination' against those who would only be eligible to receive Luxembourg financial aid. ${ }^{29}$

In 2014, the system was entirely recast through the adoption of a new legislative act. ${ }^{30}$ This new reform brought the whole system even more into line with EU law. Indeed, new article 3(5)(b) replaced the former condition of a continuous period of work of five years prior to the application for financial aid with the condition of a total period of work of five years during a reference period of seven years, thus allowing for minor breaks to be taken into account. This reform also changed the scope of the financing system by creating different types of grants in addition to the loan mechanism. As the explanatory memorandum of the draft legislation to this law stated, the objective was to rebalance the approach adopted in 2010 by taking into consideration the socio-economic background of students' household - including their parents'

\footnotetext{
27 See point 2.1. below.

${ }^{28}$ Loi du 19 juillet 2013 amending - for the third time - the Loi du 22 juin 2000 concernant l'aide financière de l'Etat pour études supérieures, Mémorial A no. 132 of 25 July 2013, p. 2724, republished in Mémorial A no. 168 of 13 September 2013, p. 3214.

${ }^{29}$ Draft legislation no.6670 of 20.03.2014, p. 3.

${ }^{30}$ Loi du 24 juillet 2014 concernant l'aide financière de l'Etat pour études supérieures, Mémorial A no. 139 of 31 July 2014, p. 2188
} 
income - while preserving the objective of making them financially independent. ${ }^{31}$ As a result of the new legislation, the grant component of the financial aid is now composed of four cumulative elements: a basic grant, a mobility grant, a social grant and a family grant when more than one child of the same family are studying contemporaneously. ${ }^{32}$ Besides, exceptional circumstances and enrolment fees may still justify an increase in the amount of the financial assistance. $^{33}$

The last revision of $2016^{34}$ has made the Luxembourg system more compliant with EU law once again. Indeed, the new legislation allows a consideration of frontier workers' step-children and children of registered partners as their children to be eligible for financial aid for higher studies. ${ }^{35}$ Other important precisions are given as regards the eligibility of the higher studies programme ${ }^{36}$ and the prevention of overlaps with financial assistance allocated by the Member State of residence. ${ }^{37}$

\section{The portability of financial aid for children of frontier workers in the case-law of the CJEU}

\subsection{Giersch: Extending portability to frontier workers}

The Giersch case related to the situation of four students - children of frontier workers - who had applied for financial aid for higher studies for the academic year 2010/2011. Their applications were rejected on the grounds that that they did not fulfil the residence condition required by the relevant legislation. They brought actions before the Administrative Court to annul these negative decisions. Their case was not an isolated occurrence since no less than 600 similar claims had been brought before the Administrative Court for the same academic year. ${ }^{38}$ The applicants claimed that the residence condition was discriminatory against frontier workers, which was prohibited by article 7(2) of Regulation no. 1612/68, now article 7(2) of regulation no. $492 / 2011^{39}$. Acknowledging that this situation might give rise to indirect discrimination,

\footnotetext{
${ }^{31}$ Draft legislation no.6670 of 20.03.2014, p. 2.

${ }^{32}$ Article 4 of Loi du 24 juillet 2014 concernant l'aide financière de l'Etat pour études supérieures.

${ }^{33}$ Article 6 of Loi du 24 juillet 2014 concernant l'aide financière de l'Etat pour études supérieures.

${ }^{34}$ Loi du 23 juillet 2016 amending the Loi du 24 juillet 2014 concernant l'aide financière de l'Etat pour études supérieures, Mémorial A no. 143 of 29 July 2016, p. 2430.

${ }^{35}$ Article $3\left(1^{\circ}\right)$ of the Loi du 23 juillet 2016.

${ }^{36}$ Article $2\left(1^{\circ}\right)$ of the Loi du 23 juillet 2016.

${ }^{37}$ Article 8 of the Loi du 23 juillet 2016.

${ }^{38}$ Giersch, paragraph 15.

${ }^{39}$ Regulation (EU) no. 492/2011 of the European Parliament and of the Council of 5 April 2011 on freedom of movement for workers within the Union, OJEU L 141/1 of 27.05.2011.
} 
the national judge asked the CJEU whether such discrimination could be justified. In its judgment, the Court starts by confirming that article 7(2) of Regulation no. 1612/68 is a 'particular expression of the principle of equal treatment enshrined in Article 45(2) TFEU'. ${ }^{40}$ Then, relying on its previous case-law, ${ }^{41}$ the Court recognises that maintenance aid to pursue higher education constitutes a social advantage within the meaning of article 7(2) of Regulation 1612/68. ${ }^{42}$ This infers that the financial aid allocated by Luxembourg for the purpose of higher studies falls within the scope of EU law and the principle of equal treatment. ${ }^{43}$ Following the reasoning of the national judge, the CJEU excludes the possibility that this condition amounts to direct discrimination based on nationality since Luxembourg nationals also have to meet this condition. ${ }^{44}$ Nevertheless, it accepts that it amount to indirect discrimination, ${ }^{45}$ which is not acceptable unless it is justified in that it relies on objective considerations of public interest and is proportionate. ${ }^{46}$ To justify this different treatment, the Luxembourg government relies both on social and budgetary considerations. While the Court rejects the argument based on budgetary constraints, it accepts that the social objective to increase significantly the proportion of Luxembourg residents holding a higher education degree is an objective of public interest, also acknowledged at the EU level. ${ }^{47}$ However, the Court carries out a proportionality test on the means used to achieve this objective. In this respect, the Court states that although the national rules are appropriate, they go beyond what is necessary to achieve this legitimate objective and are, therefore, discriminatory against frontier workers.

\subsection{Bragança Linares Verruga and Depesme: Giving more precision of the personal scope of portability}

In Giersch, Luxembourg and all governments of the intervening Member States had expressed their concern regarding the risk of 'study grant forum shopping'. To address this concern, the Court stated that this risk could be avoided by ensuring that the frontier worker had a 'sufficient

\footnotetext{
${ }^{40}$ Ibid., paragraph 35.

${ }^{41}$ Judgment of the Court of 21 June 1988, Lair v Universität Hannover, 39/86, ECLI:EU:C:1988:322, Judgment of the Court of 26 February 1992, Bernini $v$ Minister van Onderwijs en Wetenschappen, C-3/90, ECLI:EU:C:1992:89, Judgment of the Court of 8 June 1999, Meeusen v Hoofddirectie van de Informatie Beheer Groep, C-337/97, ECLI:EU:C:1999:284 and Judgment of 14 June 2012, European Commission v Kingdom of the Netherlands, C-542/09, EU:C:2012:346.

42 Giersch, paragraphs 38-39.

${ }^{43}$ Ibid., paragraph 41.

44 Ibid., paragraphs 42-43.

${ }^{45}$ Ibid., paragraph 44.

${ }^{46}$ Ibid., paragraph 46.

${ }^{47}$ Ibid., paragraphs 47-56.
} 
link' with Luxembourg society. ${ }^{48}$ The Court concretely envisioned different possibilities to ensure the existence of such a link, for instance, by making the financial aid conditional upon a 'certain minimum' period of working time. ${ }^{49}$ Moreover, referring to article 24(2) of Directive 2004/38, the Court mentioned that 'in another context', host Member States are not obliged to grant maintenance aid for studies before the acquisition of permanent residence, which implies a prior residence of five years. This latter mention is somewhat bewildering since this provision explicitly refers '...$[t]$ o persons other than workers, self-employed persons, persons who retain such status and members of their families', which is not the situation of a frontier worker. ${ }^{50}$ Following the decision of the Court, the Administrative Court adopted judgments, first to address the four claims raised in Giersch ${ }^{51}$ and second other claims where the existence of a 'sufficient link' was disputed by the Luxembourg government. ${ }^{52}$

This was precisely the question raised in Bragança Linares Verruga, where the Court examined whether imposing a period of five years of uninterrupted work in Luxembourg prior to applying for financial assistance was compatible with article 7(2) of Regulation no. 492/2011, insofar as this condition would discriminate against frontier workers. In this case, the applicant had been opposed that his parents had not been working for a continuous period of five years as required by the national legislation. Following its reasoning in Giersch, the Court stated that such a condition discriminated indirectly against frontier workers but could be justified if it fulfilled a legitimate objective and was proportionate. The Court confirmed that the objective of increasing the proportion of Luxembourg residents with higher education was legitimate. It also confirmed its perception that 'indirectly discriminatory national legislation restricting the grant to frontier workers of social advantages (...) where there is not a sufficient connection to the society in which they are pursuing their activities without residing there may be objectively justified and proportionate to the objective pursued. ${ }^{53}$ Relying on its position in Geven, ${ }^{54}$ the Court confirmed that in the case of frontier workers, Member State may provide that only those who carry out an occupation 'exceeding the threshold of minor employment' could claim the

\footnotetext{
${ }^{48}$ Ibid., paragraph 80.

${ }^{49}$ Giersch, paragraph 79.

${ }^{50}$ In Bragança Linares Verruga, the Court explained that when mentioning this article, it was simply 'drawing inspiration, by analogy...' from it. Following the Opinion of Advocate General Wathelet, the Court then confirmed that this analogy was irrelevant for imposing such a condition on frontier workers, insofar as they were workers, thus enjoying de lege equal treatment. Bragança Linares Verruga, paragraphs 65-66.

${ }^{51}$ Administrative Court: decisions of 14 October 2013 (applications nos.: 27576a, 27679a, 27689a and 28442a).

${ }^{52}$ Administrative Court: decisions of 2 December 2013 (applications nos.: 28182, 28366, 29345 and 32742 ).

${ }^{53}$ Ibid., paragraph 51.

${ }^{54}$ Judgment of the Court of 18 July 2007, Wendy Geven v Land Nordrhein-Westfalen, C-213/05, EU:C:2007:438.
} 
benefit of social advantages under article 7(2) of Regulation 492/2011, since they have established a 'real link' with the society of that Member State through their contribution to its labour market. ${ }^{55}$ Therefore, the Court held that such a condition was appropriate. However, it considered it excessive insofar as it did not allow consideration of short breaks in the working period, 'inasmuch as such breaks are not liable to sever the connection between the applicant for financial aid ${ }^{56}$ and Luxembourg. Although this outcome is once more favourable to the applicants, it is unsure whether the Court's answer will be useful beyond that specific case. This is even less likely as the 2014 legislative revision had already allowed minor breaks in the working period of the frontier worker parent. Actually, it appears that the Court did not answer the question asked by the referring court, which was whether the mere imposition of this condition as a way to assess the degree of attachment between the frontier worker and Luxembourg society was proportionate, insofar as it did 'not take into account any other connecting factor' and might have been too exclusive as a result. ${ }^{57}$ While the Court seems to accept the imposition of a condition of five years of work as a minimum in principle - it stresses that both the applicant's parents have worked for a 'total period exceeding five years ${ }^{58}$ - it does not provide sufficient guidance as to which circumstances would be liable or not to sever the connection between the worker and its country of occupation. ${ }^{59}$

The question addressed in Depesme focused on the very concept of 'child' of a frontier worker. In this case, step-children of frontier workers had applied for financial aid for higher studies and their applications had been rejected on the basis that they could not be considered children of those workers. They brought actions before the Luxembourg Administrative Court, which also rejected their claims on the grounds that their relation with their step-parent frontier worker did not fulfil the legal requirements of the Luxembourg civil code's definition of a 'childparent' relationship. ${ }^{60}$ Three of these applicants, lodged appeals before the Higher Administrative Court, which subsequently referred a request for a preliminary ruling to the CJEU. ${ }^{61}$ The referring court was essentially asking whether the child-parent relationship as laid

\footnotetext{
${ }^{55}$ Bragança Linares Verruga, paragraph 52.

${ }^{56}$ Ibid., paragraph 69.

${ }^{57}$ Ibid., paragraphs 29-30.

${ }^{58}$ Ibid., paragraph 68.

${ }^{59}$ For more a more detailed critical analysis of this point, see: A. Turmo, 'Accès des frontaliers aux aides aux études luxembourgeoises - Des precisions insatisfaisantes sur l’arrêt Giersch’, Revue des Affaires Européennes, 2016(4), pp. 701-712, read especially : pp. 710-712.

${ }^{60}$ Administrative Court: decisions of 5 January 2015 (applications nos.: 33791, 33928, 33961 and 34436) and decisions of 18 May 2015 (applications nos.: 34717 and 34790).

${ }^{61}$ Higher Administrative Court: decisions of 22 July 2015 (applications nos.: 35820C, 35848C and 35851C).
} 
down in the relevant EU law on equal treatment between workers included relationship between a worker and their step-children or the children of their registered partners. It also wondered whether the extent to which the frontier worker actually contributed to the maintenance of the child was relevant.

In its ruling, the Court favours an approach that ensures the conceptual uniformity of the concept of 'child' in EU law. Indeed, it states that the definition of this concept in the context of article 7(2) of Regulation 492/2011 is the same as the notion of 'child' under article 2(2)(c) of Directive 2004/38. This latter article encompasses as family members 'direct descendants who are under the age of 21 or are dependants and those of the spouse or [registered] partner'. As the Court argues, this provision actually 'absorbed' the substance of former article 10(1)(a) of Regulation 1612/68, which already included the children of the spouse of a migrant worker in its scope. ${ }^{62}$ This approach is supported by recital 1 of Directive 2014/54 ${ }^{63}$ which states that family members of the EU moving workers 'should be understood as having the same meaning as the term defined in point (2) of Article 2 of Directive 2004/38 (...) which applies also to family members of frontier workers. ${ }^{64}$ Since the scope of that directive is identical to the one of Regulation 492/2011, ${ }^{65}$ the definition of 'child' stemming from Directive 2014/54 is deemed to be the same as the one adopted to define the beneficiaries of equal treatment under article 7(2) of Regulation 492/2011. As to the extent of the worker's contribution, the Court adopts a broad interpretation of this condition. ${ }^{66}$ Relying on article 2(2)(c) of Directive 2004/38, the Court first states that children under 21 are presumed to be dependent. ${ }^{67}$ Above that age, the Court rules that the status of dependent child results from a 'factual situation' 68 that should be assessed by the national court on a case-by-case basis, thus excluding a formalistic approach. Such assessment should rest on 'objective factors', 69 such as a 'joint household shared [by the frontier worker] and the student'. ${ }^{70}$ The Court wishes to exclude restrictive conditions by requiring that such objective assessment excludes determining 'the reasons for the frontier

\footnotetext{
62 Ibid., paragraphs 42-49.

${ }^{63}$ Directive 2014/54/EU of the European Parliament and of the Council of 16 April 2014 on measures facilitating the exercise of rights conferred on workers in the context of freedom of movement for workers, OJEU L 128/8 of 30.04.2014.

${ }^{64}$ Depesme, paragraph 53.

${ }^{65}$ Article 2(2) of Directive 2014/54. Depesme, paragraph 54.

${ }^{66}$ Depesme, paragraph 58.

${ }^{67}$ Ibid., paragraph 62.

${ }^{68}$ Ibid., paragraph 58 and 60.

${ }^{69}$ Ibid., paragraph 60

${ }^{70}$ Ibid.
} 
worker's contribution to the maintenance of the student' or a 'precise estimation of its amount'. ${ }^{71}$

\section{Remaining challenges and emerging issues}

The Court has clearly been favourable to extending portability of financial assistance for higher studies to the children of frontier workers. However, in doing so - and even though the result was eventually favourable to the claimants - the Court might have further 'scraped' the unity of the concept of 'worker' under EU law, by creating a distinction on the basis of an integration condition that is relatively obscure. Indeed, the current situation is uncertain as regards the specific scope of the integration conditions to be imposed on frontier workers, as opposed to resident nationals and EU migrant workers. Moreover, the current case-law has not address some issues that are emerging at the national level yet.

\subsection{The integration conditions for frontier workers: fragmenting the status of $E \mathbf{U}$ workers?}

In paragraph 65 of the Giersch judgement, the Court declared rather enigmatically that: ‘... [I]t must be noted that the frontier worker is not always integrated in the Member State of employment in the same way as a worker who is resident in that State. ${ }^{72}$ Following this statement the Court accepted that a residence condition might be appropriate to reach the objective of increasing the proportion of the resident active population with a higher degree in Luxembourg. A similar reasoning was adopted in Commission $v$ The Netherlands ${ }^{73}$, where the Court accepted that a condition of residence of three years out of six year preceding the application for a maintenance grants could be appropriate to reach the objective of promoting students mobility for the benefit of the Netherlands society at large. However, the assumption

\footnotetext{
${ }^{71}$ Ibid.

${ }^{72}$ Interestingly, in Bragança Linares Verruga, the Court rather focused on the fact that because the recipients of the financial aid were not the frontier workers themselves but their non-resident children, 'the link with Luxembourg society may, in this respect, be less apparent in (...) [their case] than in the case of the children of migrant workers resident in Luxembourg', paragraph 56. As Denis Martin had anticipated, this introduces a fundamental difference between this two types of children of EU migrant workers based on the working status of their parents: D. Martin “Arrêts “Giersch” et “Prinz”: les différents statuts de l'étudiant', Journal de droit européen, vol. 201, 2013, pp. 270-274. For a similar conclusion, read: A. Iliopoulou-Penot, 'Le rattachement à l'Etat comme critère de l’intégration sociale’, Revue des Affaires Européennes, 2013, pp. 651-665, at p. 655. For a more general analysis of the notion of integration in the case-law of the CJEU, read also: E. Neframi, 'Principe d'intégration et pouvoirs de l'Etat membre', Revue des Affaires Européennes, 2013, pp. 705-714.

${ }^{73}$ For a detailed analysis of this case, see: F. De Witte, 'Who funds the mobile student? Shedding some light on the normative assumptions underlying EU free movement law: Commission v. the Netherlands', Common Market Law Review, vol. 50, 2013, pp. 203-215.
} 
that resident students are more likely to return to the labour market of their host Member State after completing their studies abroad might be considered flawed in both cases. Indeed, nothing guarantees a Member State that financing the higher studies of its nationals or children of resident migrant workers abroad will lead them to work in that Member State. ${ }^{74}$ Even if Giersch may rightly be considered a 'specific “Luxembourg” compromise' tailored to the peculiarities of Luxembourg labour market, ${ }^{75}$ it confirms that frontier workers may be imposed additional integration requirements to compensate for the non-resident status.

In Giersch, the Court confirmed that residence may be considered one of the factors ascertaining the existence of a 'real link' between the worker and the host Member State, ${ }^{76}$ although it cannot be exclusive and other elements must be taken into account. ${ }^{77}$ This is particularly sensitive for frontier workers who are by definition non-resident but who should benefit from the presumption of satisfying the criterion of integration as workers. They may substantiate their 'real link' with their Member State of work, either given their social integration $^{78}$ or through the existence or a long-term economic connection with this State. ${ }^{79}$ Nevertheless, the Court's case-law remains unclear as to the way in which such link should be assessed. This makes the extent to which frontier workers are covered by article 7(2) of regulation 492/2011 unstable.

\subsection{The material scope of portable financial aid for higher studies: restricting the personal scope through the 'back door'?}

As shown above, the personal scope of eligibility to financial aid for higher studies has been progressively widened in favour of children of frontier workers. This is a welcome change for frontier workers in Luxembourg, despite the uncertainty that still surrounds their integration conditions. Nevertheless, this positive evolution might be somewhat limited by two hurdles stemming from national law as regard the scope ratione materiae of financial assistance. Two issues deserve particular attention: the eligibility rules regarding the higher education

\footnotetext{
${ }^{74}$ See the Opinion of Advocate General Sharpston in Commission v The Netherlands, paragraph 147.

${ }^{75}$ S. O’Leary, 'The curious case of frontier workers and study finance: Giersch', Common Market Law Review, vol. 51, 2014, pp. 601-622, at p. 621.

${ }^{76}$ Giersch, paragraph 64-65. For critical analyses of the notion of 'real link', read: P. J. Neuvonen, 'In search of (even) more substance for the "real link" test: comment on Prinz and Seeberger', European Law Review, vol. 39(1), 2014, pp. 125-136.

77 Giersch, paragraph 72. See also for instance: Judgment of the Court of 18 July 2007, Gertraud Hartmann v Freistaat Bayern, C-212/05, EU:C:2007:437.

${ }^{78}$ See for instance: Judgment of the Court of 25 October 2012, Déborah Prete v Office national de l'emploi, C367/11, EU:C:2012:668, paragraph 50.

${ }^{79}$ Giersch, paragraph 81.
} 
programme and the rules to prevent overlap between Luxembourg maintenance scheme and financial assistance provided to students by the Member State of residence.

As for the eligibility of the higher education programme in which a student is enrolled, article 2(1) of the legislation in force (as modified in 2016) ${ }^{80}$ requires that it is recognised by the State of registration as being part of its higher education system, insofar as it leads to the conferral of an academic degree. This excludes diplomas or certificates delivered by higher education institutions, which are not formally recognised as national academic degrees. ${ }^{81}$ Although this is perfectly legitimate, as far as higher education falls within the realm of Member States in accordance with article 165(1) TFEU, it does not take into account the complexity of higher education systems in all Member States.

Finally, the rules preventing the overlap between Luxembourg financial aid and financial assistance provided to the student in the State of residence are set out in article 8 of the current legislation (as modified in 2016). ${ }^{82}$ These rules not only concern similar financial aid for the purpose of higher studies but they also target other financial advantages granted to the student or the household to which s/he belongs, such as family allowances. ${ }^{83}$ Besides, students have to ask for financial assistance in their Member State of residence and justify why they were not granted such assistance in order to be eligible for Luxembourg financial aid. ${ }^{84}$

\footnotetext{
${ }^{80}$ Loi du 23 juillet 2016.

${ }^{81}$ This is the case of a university certificate in psychology delivered by a Belgian University (Administrative Court, decision of 22 October 2014, application no. 32193) or the certificate of a private institution for higher education in France, which is delivered in partnership with national universities (Administrative Court, decision of 14 December 2015, application no. 35733, confirmed on appeal: Higher Administrative Court, decision of 24 January 2017, application no. 38145C).

${ }^{82}$ Loi du 23 juillet 2016.

${ }^{83}$ For instance, regarding family allowances granted to students above 18 in Belgium, see: Administrative Court, decision of 1st June 2016, application no. 36209, confirmed on appeal: Higher Administrative Court, decision of 16 February 2017, application no. 38151C.

${ }^{84}$ Administrative Court, decision of 18 October 2017, application no. 38250.
} 